\title{
HA-966 Antagonizes N-Methyl-D-Aspartate Receptors through a Selective Interaction with the Glycine Modulatory Site
}

\author{
Alan C. Foster and John A. Kemp \\ Merck Sharp and Dohme Research Laboratories, Neuroscience Research Centre, Harlow, Essex, CM20 2QR, England
}

3-Amino-1-hydroxypyrrolid-2-one (HA-966) has been known for several years as an excitatory amino acid antagonist, acting principally at the $N$-methyl-D-aspartate (NMDA) receptor subtype. We report here that HA-966 blocks NMDA responses through a selective interaction with the glycine modulatory site present within the receptor complex. In radioligand binding experiments, HA-966 inhibited strychnineinsensitive ${ }^{3} \mathrm{H}$-glycine binding to rat cerebral cortex synaptic plasma membranes with an $\mathrm{IC}_{50}$ of $17.5 \mu \mathrm{M}$. At concentrations up to $1 \mathrm{mM}$, HA-966 caused minimal inhibition of radioligand binding to the transmitter recognition sites of the NMDA, quisqualate, or kainate receptor subtypes and was similarly inactive against the binding of ${ }^{3} \mathrm{H}$-strychnine to rat spinal cord/brain stem membranes. In electrophysiological experiments, HA-966 produced a selective block of NMDA responses in a rat cortical slice preparation. The degree of antagonism caused by HA-966 was maximal at $250 \mu \mathrm{M}$ and was not increased further by raising the HA-966 concentration. Both glycine $(1 \mathrm{mM})$ and $\mathrm{D}$-serine $(100 \mu \mathrm{M})$ reversed the antagonism of NMDA responses caused by HA-966. In patchclamp experiments using rat cortical neurons in culture, HA966 blocked the potentiation of NMDA responses by glycine but had little effect on basal NMDA responses themselves. This profile of antagonism differs from that observed with 7-chlorokynurenate, another recently discovered antagonist of the glycine site on the NMDA receptor (Kemp et al., 1988) and may indicate that glycine antagonists of differing efficacies can exist. Previous experiments with HA-966 may now be interpreted to suggest that activation of the glycine site on the NMDA receptor occurs in vivo and is important for the participation of NMDA receptors in synaptic transmission.

The $N$-methyl-D-aspartate (NMDA, or AA-1) receptor is the best characterized of the receptor subtypes mediating the effects of the excitatory amino acid neurotransmitters (Watkins and Evans, 1981; Dingledine, 1986; Foster and Fagg, 1987a). Both competitive antagonists, c.g., D-2-amino-5-phosphonovalerate (D-AP5; Evans et al., 1982), which act at the transmitter rec-

\footnotetext{
Received Aug. 24, 1988; revised Oct. 27, 1988; accepted Oct. 28, 1988.

We are grateful to Tony Priestley for preparing the neuronal cultures and contributing to some of the cortical slice experiments, to Robcrt Tridgctt and Sarah Grimwood for assistance with some of the radioligand binding experiments, and to Eleanor Brawn for secretarial assistance. J. A. K. would like to thank Drs. J. Johnson and P. Ascher for allowing him to visit their laboratory to learn patchclamp techniques.

Correspondence should be addressed to either author at Merck Sharp and Dohme Research Laboratories, Neuroscience Research Centre, Terlings Park, Eastwick Road, Harlow, Essex, CM20 2QR, UK.

Copyright (C) 1989 Society for Neuroscience $0270-6474 / 89 / 062191-06 \$ 02.00 / 0$
}

ognition site, and noncompetitive antagonists, e.g., $\mathrm{Mg}^{2+}$, phencyclidine, and MK-801 (Anis et al., 1983; Nowak et al.,1984; Wong et al., 1986; Kemp et al., 1987), which act at the ion channel, have been described for the NMDA receptor.

Recently, Johnson and Ascher (1987) provided evidence for a further sitc on the receptor that may allosterically regulate receptor activation. Using patch-clamp techniques, they showed that NMDA receptor responses in cultured cerebral neurons were greatly potentiated in the presence of low concentrations of glycine. This effect was strychnine insensitive, and therefore unrelated to the classical inhibitory glycine receptor, and did not involve intracellular messengers. The effect of glycine was to increase the frequency of channel opening (Johnson and Ascher, 1987). The idea that a "glycine site" exists on the NMDA receptor is supported by the distribution of strychnine-insensitive ${ }^{3} \mathrm{H}$-glycine binding sites as determined autoradiographically in rat brain sections (Bristow et al., 1986), which closely parallels that of NMDA receptors labeled by $\mathrm{L}^{3} \mathrm{H}$-glutamate (Monaghan and Cotman, 1985). Subsequently, several groups have reported that glycine, $\mathrm{D}$-serine, and other amino acids that compete at strychnine-insensitive ${ }^{3} \mathrm{H}$-glycine binding sites can potentiate the ability of NMDA receptor agonists to increase the binding of ${ }^{3} \mathrm{H}$-thienylcyclohexylpiperidine (TCP) and ${ }^{3} \mathrm{H}$ MK-801 (Bonhaus et al., 1987; Reynolds et al., 1987; Snell et al., 1987; Wong et al., 1987; Kloog et al., 1988; Thomas et al., 1988). Further evidence in support of an allosteric site for glycine on the NMDA receptor complex has come from the finding that 7-chlorokynurenate (7-C1KYNA) antagonizes NMDA responses by a selective action at this site (Kemp et al., 1988).

3-Amino-1-hydroxypyrrolid-2-one (HA-966) was one of the first substances proposed as an antagonist of excitatory amino acid receptors (Davies and Watkins, 1972, 1973a; Curtis et al., 1973). In the spinal cord, HA-966 has the profile of an NMDA receptor antagonist (Biscoe et al., 1978; Evans et al., 1978); however, this compound is structurally unrelated to any of the competitive or noncompetitive NMDA antagonists described to date. Here, we present evidence that HA-966 has a selective action at the glycine modulatory site of the NMDA receptor complex but possesses a different profile as an antagonist of NMDA receptor-mediated responses to that of $7-\mathrm{C} 1 \mathrm{KYNA}$.

\section{Materials and Methods}

Radioligand binding experiments. NMDA-sensitive $\mathrm{L}^{-}{ }^{3} \mathrm{H}$-glutamate binding to crude postsynaptic densities (PSD) from rat cerebral cortex was determined as described by Foster and Fagg (1987b). The binding of ${ }^{3} \mathrm{H}$ - $\alpha$-amino-3-hydroxy-5-methyl-4-isoxazolepropionate (AMPA) and ${ }^{3} \mathrm{H}$-kainate was also measured using crude PSD by modifications of the methods of Honore and Nielson (1985) and Simon et al. (1976). For each binding assay, crude PSD ( $50 \mu \mathrm{g}$ membrane protein) were incubated at $32^{\circ} \mathrm{C}$ for $30 \mathrm{~min}$ with $50 \mathrm{~mm}$ Tris-acetate buffer $(\mathrm{pH} 7.0)$ and either 
$50 \mathrm{nM} \mathrm{L}^{-3} \mathrm{H}$-glutamate $(40-60 \mathrm{Ci} / \mathrm{mmol}), 36 \mathrm{nM}{ }^{3} \mathrm{H}$-AMPA $(5-15 \mathrm{Ci} /$ $\mathrm{mmol}$ ), or $16 \mathrm{nM}^{3} \mathrm{H}-\mathrm{kainate}(30-60 \mathrm{Ci} / \mathrm{mmol}$; each radioligand obtained from Dupont-New England Nuclear) in a final volume of $0.5 \mathrm{ml}$. In the ${ }^{3} \mathrm{H}$-AMPA binding assays, $100 \mathrm{~mm} \mathrm{KSCN}$ was included (Honore and Nielson, 1985). Nonspecific binding was determined by the inclusion of $1 \mathrm{mM}$ L-glutamate. For $\mathrm{L}-{ }^{3} \mathrm{H}$-glutamate and ${ }^{3} \mathrm{H}$-AMPA binding assays, bound and free radioactivity were separated by centrifugation in an Eppendorf microcentrifuge. Filtration through Whatman GF/C filters using a Brandel cell harvester was used in the case of ${ }^{3} \mathrm{II}$-kainate binding. ${ }^{3} \mathrm{H}$-strychnine binding to rat brain stem/spinal cord membranes was determined as described by Young and Snyder (1974).

For ${ }^{3} \mathrm{H}$-glycine binding experiments, synaptic plasma membranes (SPM) were prepared from rat cerebral cortex as described by Foster and Fagg (1987b). However, they were not treated with Triton X-100 but frozen at $-20^{\circ} \mathrm{C}$ for at least $18 \mathrm{hr}$ before being washed 4 times by resuspension in $50 \mathrm{vol}(\mathrm{wt} / \mathrm{vol})$, with respect to original tissue weight, of $5 \mathrm{~mm}$ Tris-acetate buffer ( $\mathrm{pH} 7.0$ ) with a glass Teflon homogenizer and centrifugation at $50,000 \times g$ for $60 \mathrm{~min}$. The final pellet was resuspended in a small volume of $5 \mathrm{~mm}$ Tris-acetate $(\mathrm{pH} 7.0)$ to give a membrane protein concentration of approximately $3 \mathrm{mg} / \mathrm{ml}$ and stored at $-80^{\circ} \mathrm{C}$. For the binding assay, SPM (50-100 $\mu \mathrm{g}$ membrane protein) were incubated at $4^{\circ} \mathrm{C}$ for $30 \mathrm{~min}$ with $50 \mathrm{~mm}$ Tris-acetate buffer $(\mathrm{pH}$ 7.0 ) and $50 \mathrm{nM}^{3} \mathrm{H}$-glycinc (40-60 Ci/mmol; Dupont-New England Nuclear) in a final volume of $0.5 \mathrm{ml}$. Nonspecific binding was determined by the inclusion of $1 \mathrm{~mm}$ glycine, and bound radioactivity was separated by centrifugation in an Eppendorf microcentrifuge.

Rat cortical slice recordings. Population depolarizations of rat cortical tissue induced by excitatory amino acids were recorded using a greasedgap technique in a manner similar to that first described by Harrison and Simmonds (1985). Male Sprague-Dawley rats, weighing approximately $100 \mathrm{gm}$, were killed by decapitation and their brains rapidly removed. A 3- to 4-mm-thick coronal slice was cut by hand from an area delineated rostrally by the olfactory tubercle and caudally by the optic chiasm. The rostral surface of the section was fixed, using cyanoacrylic glue, to a glass slide attached to an aluminum block and mounted on the stage of an Oxford vibratome. The section was completely immersed in continuously gassed $\left(95 \% \mathrm{O}_{2} / 5 \% \mathrm{CO}_{2}\right)$ artificial cerebrospinal fluid (aCSF), at room temperature, of the following composition (in mM): $\mathrm{NaCl}, 124 ; \mathrm{MgSO}_{4}, 2 ; \mathrm{KCl}, 2 ; \mathrm{KH}_{2} \mathrm{PO}_{4}, 1.25 ; \mathrm{NaHCO}_{3}$, $25 ; \mathrm{CaCl}_{2}, 2$; glucose 11 .

Coronal sections, $500 \mu \mathrm{m}$ thick, were cut using the vibratome and further dissected into $1-\mathrm{mm}$-wide wedges consisting of cortex, white matter, and underlying striatal tissue. The wedges were mounted in a 2-compartment chamber with the ventral margin of the cortical tissue traversing a greased slot in such a way that the cortical tissue lay almost entirely in one compartment and the white matter and striatal tissue within the other.

The chamber containing the cortical tissue (vol $\leq 0.3 \mathrm{ml}$ ) was continuously gravity-perfused with aCSF at a rate of $1.5-2 \mathrm{ml} / \mathrm{min}$. At this stage, $\mathrm{Mg}^{2+}$ was omitted from the aCSF to prevent the voltage-dependent block of NMDA responses by this cation, and tetrodotoxin $\left(10^{-7}\right.$ M) included to prevent spontaneous paroxysmal potentials induced by the removal of $\mathrm{Mg}^{2+}$. The d.c. potential between the 2 compartments was monitored on a potentiometric recorder via conventional $\mathrm{Ag} / \mathrm{AgCl}$ electrodes. The chamber containing the cortical tissue was always electrically grounded.

Excitatory amino acid agonists, dissolved in aCSF, were applied for periods of 1 min with a separating interval of not less than $10 \mathrm{~min}$. HA-966 was perfused for 15-30 min prior to repeating excitatory amino acid concentration-response curves.

Whole-cell patch-clamp recordings from rat cortical neurons. Primary cultures of rat cortical neurons were prepared from 1-d-old neonatal rats essentially as described by Kaplan et al. (1986). Cells were plated onto poly(D-lysine)-coated glass coverslips at a density of $1 \times 10^{5}$ cells/ coverslip and cultured in a growth medium of the following composition: Dulbecco's Modified Eagle's Medium (DMEM, Gibco) and Ham's F12 nutrient mixture (F12, Gibco) in a 2:1 ratio, supplemented with $10 \%$ donor horse serum (Gibco) and $2 \mathrm{~mm}$ glutamine (Gibco). Cultures were kept at $37^{\circ} \mathrm{C}$ in an incubator containing $5 \% \mathrm{CO}_{2}$. Cytosine arabinofuranoside $\left(10^{-5} \mathrm{M}\right.$, Sigma) was added to each dish to inhibit nonneuronal cell proliferation after attaining confluency (usually 4-5 d after plating).

For electrophysiological recordings, glass coverslips were transferred to a glass-bottomed, Perspex recording chamber mounted on the stage of a Nikon Diaphot inverted microscope. Cultures were observed using phase-contrast optics and continuously perfused (approx. $1 \mathrm{ml} / \mathrm{min}$ ) with a gassed $\left(5 \% \mathrm{CO}_{2} / 95 \% \mathrm{O}_{2}\right) \mathrm{aCSF}$ of the following composition (in $\mathrm{mM}$ ): $\mathrm{NaCl}, 124 ; \mathrm{KCl}, 2 ; \mathrm{KH}_{2} \mathrm{PO}_{4}, 1.25 ; \mathrm{MgCl}_{2}, 2 ; \mathrm{CaCl}_{2}, 2 ; \mathrm{NaHCO}_{3}$, 25; glucose, 11 .

Patch pipettes with an approximate tip diameter of $2 \mu \mathrm{m}$ were pulled using a Mechanex BBCH puller using borosilicate glass (Clarke Electromedical). No additional fire polishing was performed. These pipettes had resistances of approximately $4 \mathrm{M} \Omega$ when filled with the usual medium, which contained (in mM): $\mathrm{CsF}, 120 ; \mathrm{CsCl}, 10$; HEPES, 10; EGTA, $10 ; \mathrm{NaCl}, 4 ; \mathrm{CaCl}_{2}, 0.5 ; \mathrm{pH}$ adjusted to 7.25 with $\mathrm{CsOH}$.

Whole cell currents were recorded from cultured neurons 1-4 weeks after plating using a List EPC-7 amplifier. The headstage was mounted on a Narishige 3-dimensional hydraulic manipulator. Positive internal pressure was applied to the pipette prior to lowering it into the bath solution and maintained until contact had been established with the cell. The pressure was then released and gentle suction applied, which generally led to the formation of a high-resistance seal with the cell membrane. After clamping the patch potential to $-60 \mathrm{mV}$, further suction was applied to rupture the membrane under the patch pipette. The seal resistance prior to rupturing the membrane patch was' usually in the order of $40 \mathrm{G} \Omega$.

Drug solutions were applied to individual cells by rapid perfusion from a double-barreled pipette assembly as described by Johnson and Ascher (1987). Stepwise movement of the pipette assembly enabled rapid equilibration of either control or test solutions. $\mathrm{MgCl}_{2}$ was omitted from the pipette solutions and $0.1 \mu \mathrm{M}$ tetrodotoxin added.

Materials. HA-966 was a generous gift from Organon (The Netherlands). All other drugs and reagents were obtained from commercial sources at the highest purity available.

\section{Results}

\section{Radioligand binding experiments}

In view of its NMDA receptor antagonist effects in electrophysiological experiments (Biscoe et al., 1978; Evans et al., 1978; see below), HA-966 was tested as an inhibitor of NMDA-sensitive $\mathrm{L}_{-}{ }^{3} \mathrm{H}$-glutamate binding to crude PSD from rat cerebral cortex. HA-966 displayed negligible affinity for the recognition site of the NMDA receptor, causing $5 \pm 3 \%$ inhibition $(n=3)$ of NMDA-sensitive $\mathrm{L}^{-}{ }^{3} \mathrm{H}$-glutamate binding at a concentration of $1 \mathrm{~mm}$. HA-966 (1 mM) was similarly ineffective at the recognition sites of the quisqualate and kainate receptors, causing $4 \pm 3 \%$ and $24 \pm 6 \%$ inhibition, respectively $(n=3)$ of ${ }^{3} \mathrm{H}$ AMPA and ${ }^{3} \mathrm{H}$-kainate binding to crude PSD from rat cerebral cortex.

The binding of ${ }^{3} \mathrm{H}$-glycine to SPM from rat cerebral cortex was used to label the glycine modulatory site on the NMDA receptor complex. As previously described (Kemp et al., 1988), the binding was insensitive to strychnine and was inhibited by amino acids (Fig. 1), which act at the glycine site to potentiate NMDA responses (Reynolds et al., 1987; Wong et al., 1987). As shown in Figure 1, HA-966 inhibited ${ }^{3} \mathrm{H}$-glycine binding with an $\mathrm{IC}_{50}$ of $17.5(15.2,20.3) \mu \mathrm{M}$ [geometric mean (-SEM, + SEM) of 4 experiments]. However, the classical inhibitory glycine receptor as labeled in rat brain stem/spinal cord membranes using ${ }^{3} \mathrm{H}$-strychnine was insensitive to HA-966, which, at a concentration of $1 \mathrm{~mm}$, caused $11 \pm 10 \%$ inhibition $(n=$ 3).

These observations led us to investigate whether the block of NMDA responses by HA-966 was due to antagonism at the glycine modulatory site on the NMDA receptor complex.

\section{Cortical slice experiments}

As shown in Figure 2, HA-966 antagonized depolarizing responses to NMDA but had no effect on responses to quisqualate. At a concentration of $1 \mathrm{~mm}, \mathrm{HA}-966$ did not affect responses to kainate ( $30 \mu \mathrm{M}, n=3$; data not shown). The threshold con- 


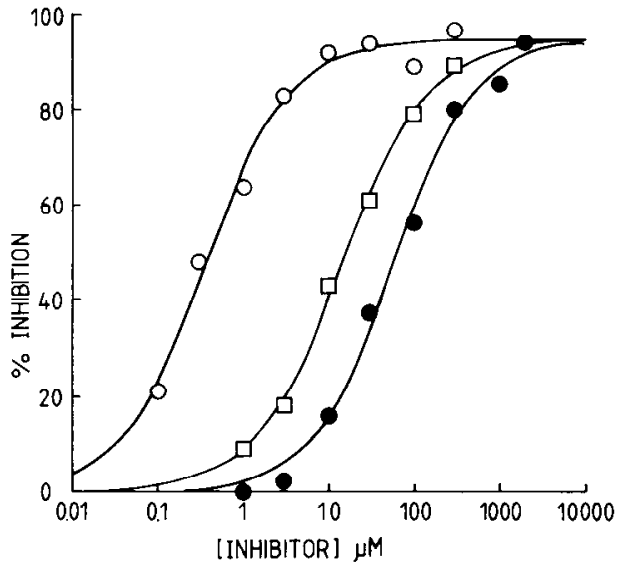

Figure 1. Inhibition of ${ }^{3} \mathrm{H}$-glycine binding to rat cerebral cortex synaptic plasma membranes by D-serine (O), L-serine (C), and HA-966 ( $\square$ ). Each curve is from a single experiment that was repeated 2-3 times with similar results. Percent inhibition data was analyzed using a 1-site model with variable slope. The equation used was: $\% I=\% I_{\max } / 1+$ $\left(\mathrm{IC}_{50} /[L]\right)^{s}$, where $I_{\max }$ is the maximum percent inhibition, $\mathrm{IC}_{50}$ is the concentration of ligand giving a $50 \%$ inhibition of binding, $[L]$ is the ligand concentration and $S$ is the slope factor (Hill coefficient). Calculations were performed using the data manipulation and analysis software RS1 (Bolt, Beranek and Newman, Inc). $\mathrm{IC}_{50}$ values in this experiment were as follows: $\mathrm{D}$-serine $=0.35 \mu \mathrm{M}$, L-serine $=56.8 \mu \mathrm{M}$, HA-966 $=14.1 \mu \mathrm{M}$. Typical levels of counts in the ${ }^{3} \mathrm{H}$-glycine binding assay were as follows: total binding $=18,521 \pm 655 \mathrm{dpm}$, nonspecific binding (in presence of $1 \mathrm{~mm}$ glycine) $=4682 \pm 372 \mathrm{dpm}(n=4)$.

centration for NMDA antagonism by HA-966 was $100 \mu \mathrm{M}$ (Table 1). The degree of antagonism increased at a concentration of $250 \mu \mathrm{M}$, but raising the HA-966 concentration to 500 and $1000 \mu \mathrm{M}$ produced no further significant increases in the NMDA antagonism.

Glycine (1 mM) was able to completely reverse the antagonism of NMDA responses produced by HA-966 $(100 \mu \mathrm{M}$; Fig. $3 A)$. On 4 slices the mean log concentration-ratio produced by HA-

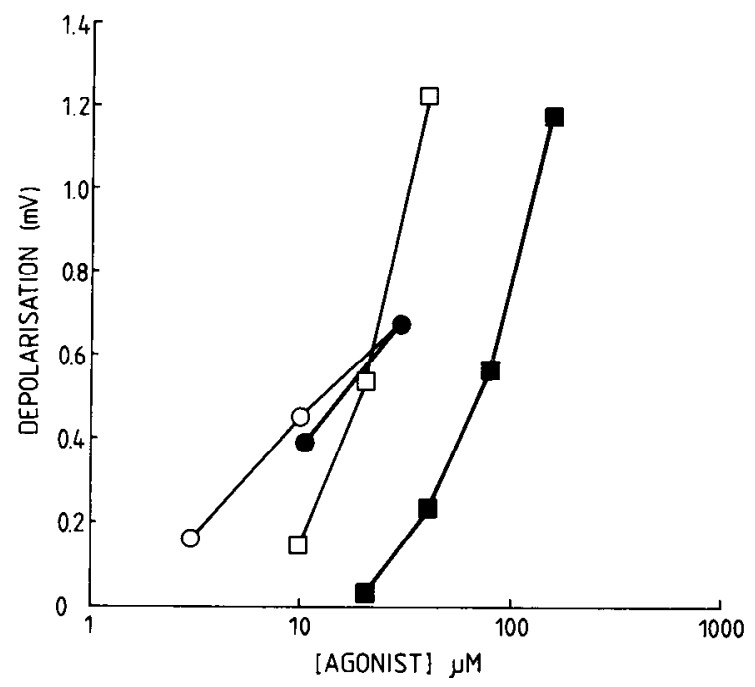

Figure 2. Selective antagonist effects of HA-966 on NMDA-induced depolarizations of a rat cortical slice. Concentration-response curves for NMDA $(\square, \square)$ and quisqualate $(O, \oplus)$ before (open symbols) and after (closed symbols) HA-966 (500 $\mu \mathrm{M})$. HA-966 was without effect on responses to 10 and $30 \mu \mathrm{M}$ quisqualate but antagonized responses to NMDA resulting in a rightward shift of the concentration-response curve.

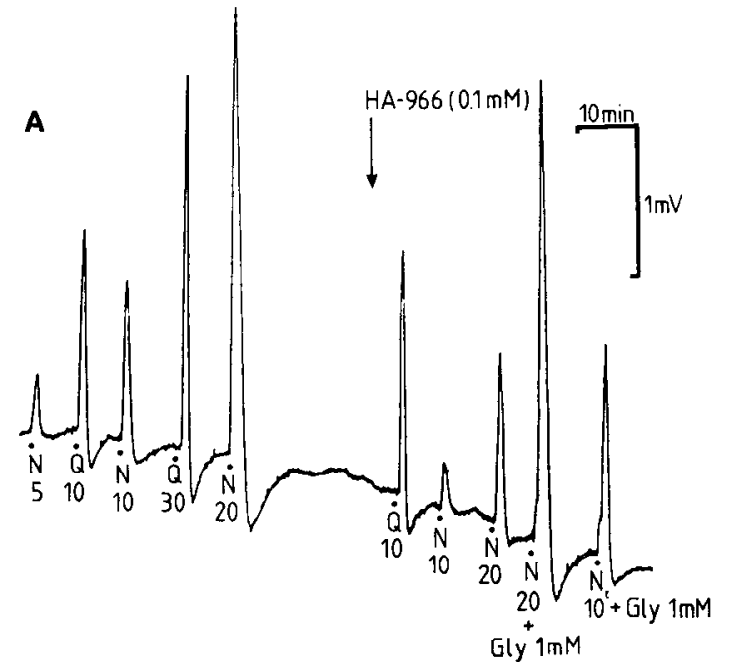

$\mathbf{B}$

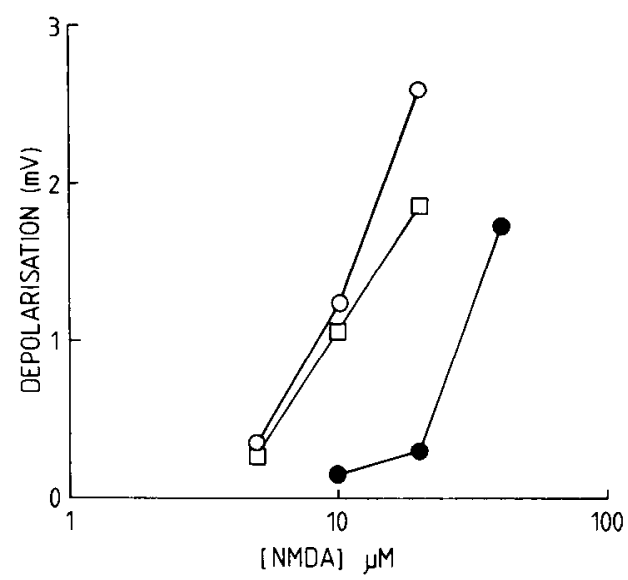

Figure 3. A, Reversal of the NMDA antagonist effect of HA-966 $(0.1$ $\mathrm{mM}$ ) by glycine (1 $\mathrm{mM})$. Trace of depolarizations produced by $1 \mathrm{~min}$ applications of NMDA $(N)$ and quisqualate $(Q)$ (numbers indicate concentration in $\mu \mathrm{M})$. HA-966 (0.1 mM, from arrow) reduced the responses to NMDA but not quisqualate. Coadministration of glycine ( $1 \mathrm{mM}, 1$ min before and during the NMDA application) reversed the antagonist effect of HA-966. At this concentration glycine produced a small depolarization of its own. $B$, Reversal by D-serine of the NMDA antagonism produced by HA-966 on a rat cortical slice. NMDA responses were obtained before $(O)$ and in the presence of $1 \mathrm{mM} \mathrm{HA}-966(0)$ (perfused for $15 \mathrm{~min}$ prior to repeating the NMDA applications). HA966 antagonized the NMDA responses, resulting in a shift of the concentration-response curve to the right. Co-perfusion of D-serine $(0.1$ $\mathrm{mM}$ ) with the HA-966 (for $15 \mathrm{~min}$ ) reversed this NMDA antagonism and returned the NMDA response ( $\square$ ) back almost to control levels.

$966(100 \mu \mathrm{M})$ was reduced from $0.26 \perp 0.05$ to $0.04 \pm 0.03$ by glycine $(1 \mathrm{mM})$. Furthermore, D-serine $(100 \mu \mathrm{M})$, another agonist at the glycine site, was able to almost completely reverse the effects of $1 \mathrm{~mm}$ HA-966, reducing the mean log concentrationratio from $0.47 \pm 0.02$ to $0.08 \pm 0.018(n=3$; Fig. $3 B)$. HA966 , even at the highest concentrations tested, produced no obvious flattening of the NMDA concentration-response curve, although only a limited agonist concentration range was studied because of the neurotoxic effects of high agonist concentrations.

\section{Whole-cell patch-clamp experiments}

Whole-cell patch-clamp recordings were made from rat cortical neurons in primary cell culture to examine the effects of HA- 


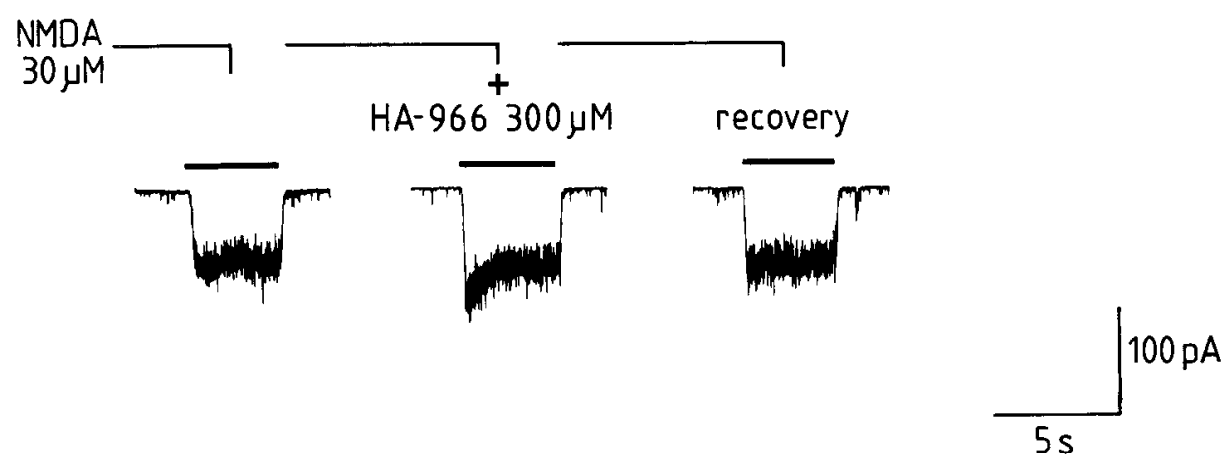

Figure 4. Antagonism by HA-966 of the glycine potentiation of NMDA-induced inward currents in a rat cultured cortical neuron. Whole-cell currents recorded at a holding potential of -60 $\mathrm{mV}$. HA-966 $(300 \mu \mathrm{M})$ had no antagonist effect on basal NMDA $(30 \mu \mathrm{M})$ responses obtained in the absence of any added glycine. Addition of glycine $(1 \mu \mathrm{M})$ resulted in a large potentiation of the NMDA response, and this effect was reversibly antagonized by HA-966 $(300 \mu \mathrm{M})$.

966 on NMDA responses in conditions under which extracellular glycine concentrations could be more easily controlled. Addition of glycine $(1 \mu \mathrm{M})$ always resulted in a large potentiation of the NMDA (30 $\mu \mathrm{M})$ response (Fig. 4) which could be as great as a 50 -fold increase in the size of the induced current. HA966 , at concentrations up to $1 \mathrm{mM}$, had no antagonist effect on basal responses to NMDA $(30 \mu \mathrm{M})$ evoked in the absence of added glycine (Fig. 4). However, the potentiation of NMDA responses by glycine $(1 \mu \mathrm{M})$ was reduced by HA-966 (100-300 $\mu \mathrm{M})$, as illustrated in Figure 4. On a further 4 cells, $30 \mu \mathrm{M}$ HA966 reduced the potentiation caused by $300 \mathrm{nM}$ glycine almost to basal levels [relative to responses evoked by $10 \mu \mathrm{M}$ NMDA alone, the mean $( \pm$ SEM) percentage values were: $10 \mu \mathrm{M}$ NMDA $+300 \mathrm{nM}$ glycine $=770 \pm 90 \%$ and $10 \mu \mathrm{M}$ NMDA $+300 \mathrm{nM}$ glycine $+30 \mu \mathrm{M}$ HA-966 $=160 \pm 17 \%]$.

Table 1. Antagonism of NMDA responses on rat cortical slices by HA-966

\begin{tabular}{cll} 
HA-966 $(\mu \mathrm{M})$ & $\begin{array}{l}\text { Log concentration-ratio } \\
(\text { mean } \pm \text { SEM) }\end{array}$ & $(n)$ \\
\hline 50 & $0.05 \pm 0.04$ & $(3)$ \\
100 & $0.21 \pm 0.04$ & $(7)$ \\
250 & $0.47 \pm 0.04$ & $(4)$ \\
500 & $0.53 \pm 0.04$ & $(4)$ \\
1000 & $0.47 \pm 0.02$ & $(3)$
\end{tabular}

Shift in the NMDA concentration-response curve caused by increasing concentrations of HA-966. Note that a maximal shift is achieved at $250 \mu \mathrm{M} \mathrm{HA}-$ 966 , and no further significant effect is obtained at 500 or $1000 \mu \mathrm{M}$.

\section{Discussion}

The radioligand binding and electrophysiological results presented here indicate that IIA-966 is a specific antagonist at the glycine modulatory site on the NMDA receptor complex. Thus, the antagonism by HA-966 of NMDA responses in intact cortical slices and cortical neurons in culture was reversed by glycine and D-serine (note that glycine agonists do not affect the blockade of NMDA responses by competitive or noncompetitive NMDA antagonists: Kemp et al., 1988). While this paper was in preparation, a report appeared by Fletcher and Lodge (1988) who have obtained preliminary evidence that the antagonism of NMDA responses in rat cortical slices by HA-966 can be reversed by glycine. Among binding sites associated with excitatory amino acid receptors, HA-966 was highly selective for the glycine site, having little affinity for the recognition sites of the NMDA, quisqualate, and kainate receptors. The poor ability of HA-966 to inhibit ${ }^{3} \mathrm{H}$-strychnine binding indicates that it has a low affinity for the classical inhibitory glycine receptor, in agrecment with clectrophysiological studics indicating that the antagonism of excitatory amino acid responses by HA966 is not mediated by an agonist action at this inhibitory receptor (Davies and Watkins, 1972, 1973a; Curtis et al., 1973).

In rat cortical slice preparations, the glycine modulatory site on the NMDA receptor appears to be maximally activated since addition of exogenous glycine or $\mathrm{D}$-serine does not potentiate responses to NMDA (cf. Kemp et al., 1988). Therefore, the antagonism of NMDA responses by HA-966 in this preparation appears to be the result of competition with endogenous activators of the glycine site (presumably glycine itself). Thus, it is interesting that the antagonism of NMDA responses by HA- 
966 reaches a maximal value (Table 1) beyond which raising the HA-966 concentration results in no further block of the NMDA response. This may suggest that HA-966 blocks only the component of the NMDA response that is potentiated by glycine. This hypothesis was supported by the patch-clamp experiments in which HA-966 was able only to antagonize that part of the NMDA response which was potentiated by glycine, and was without effect on basal NMDA responses obtained in the absence of exogenous glycine. These results with HA-966 differ from those recently obtained using 7-Cl KYNA, another compound that appears to be an antagonist at the glycine modulatory site on the NMDA receptor (Kemp et al., 1988). In the rat cortical slice, 7-Cl KYNA can produce a complete flattening of the NMDA concentration-response curve, and in patch-clamp experiments 7-Cl KYNA can completely block both the glycine potentiation of NMDA responses and basal NMDA responses evoked in the absence of added glycine. All of these effects can be reversed by the addition of glycine or D-serine and occur at concentrations of 7-Cl KYNA below those necessary for an interaction with the transmitter recognition site of the NMDA receptor (Kemp et al., 1988). One possible explanation for the different properties of $\mathrm{H} \Lambda-966$ and $7-\mathrm{Cl} \mathrm{KYNA}$ is that they may act at the glycine modulatory site on the NMDA receptor in an analogous way to the interactions of ligands for the benzodiazepine site on the $\mathrm{GABA}_{\mathrm{A}}$ receptor complex. Thus, HA-966 may be an antagonist (i.e., possessing no intrinsic activity) that simply blocks the action of an agonist such as glycine (positive modulator), and 7-Cl KYNA may be an inverse agonist (negative modulator) that allosterically reduces receptor activity. An alternative possibility is that HA-966 is a weak partial agonist at the glycine site which cannot cause appreciable potentiation of the NMDA response and that 7-CI KYNA is a true antagonist. This would imply that activation of the glycine site is an absolute requirement for NMDA receptor activation. Indeed, this has recently been suggested by Kleckner and Dingledine (1988) based on their experiments with NMDA receptors expressed in Xenopus oocytes following injection of rat brain messenger RNA. The response shown in Figure 4 was the most obvious example of a potentiation of basal NMDA responses by HA-966 obtained, but in general no difference from basal values was observed. In fact, sometimes a small and incomplete inhibition of basal NMDA responses by HA-966 was apparent, but this occurred in neurons that showed a relatively large basal response to NMDA and a smaller than average potentiation by glycine, suggesting that extracellular glycine levels were already quite high. If HA-966 is a partial agonist, it must possess a relatively low efficacy.

The realization that HA-966 antagonizes the ability of glycine to potentiate NMDA responses raises some interesting points in relation to previous in vivo studies carried out with this compound. The fact that HA-966 antagonizes responses to iontophoretically applied NMDA receptor agonists (Davies and Watkins, 1972, 1973a, b; Curtis et al., 1973; Clarke and Straughan, 1977; Biscoe et al., 1978; Kemp and Sillito, 1982) suggests that activation of the glycine modulatory site occurs in vivo. Furthermore, synaptic responses in the cuneate nucleus (Davies and Watkins, 1973a, b), on Renshaw cells (Curtis et al., 1973), in the dorsal lateral geniculate nucleus in response to visual stimulation (Kemp and Sillito, 1982), and in the spinal cord (Evans et al., 1978) are reduced by HA-966. Thus, activation of the glycine modulatory sitc appcars to bc important in synaptic responses mediated by NMDA receptors. HA-966 is also re- ported to possess antitremor and anticonvulsant activity in certain animal models (Bonta et al., 1971; Menon, 1981).

If the effects of HA-966 previously observed in vivo are due to a blockade of the potentiation of NMDA receptor-mediated responses by glycine, the existing data indicate the importance of this interaction for CNS function. It is hoped that HA-966 will be a useful tool in the further investigation of the modulatory glycine site on the NMDA receptor and the role it plays under both physiological and pathophysiological conditions.

\section{References}

Anis, N. A., S. C. Berry, N. R. Burton, and D. Lodge (1983) The dissociative anaesthetics ketamine and phencyclidine selectively reduce excitation of central mammalian neurones by $\mathrm{N}$-methyl-aspartate. Br. J. Pharmacol. 79: 565-575.

Biscoe, T. J., J. Davies, A. Dray, R. H. Evans, M. R. Martin, and J. C. Watkins (1978) $\mathrm{D}-\alpha$-aminoadipate, $\alpha, \xi$-diaminopimelic acid and HA-966 as antagonists of amino acid-induced and synaptic excitation of mammalian spinal neurones in vivo. Brain Res. 148: 543-548.

Bonhaus, D. W., B. C. Burge, and J. O. McNamara (1987) Biochemical evidence that glycine allosterically regulates an NMDA receptor-coupled ion channel. Eur. J. Pharmacol. 142: 489-490.

Bonta, I. L., C. J. De Vos, H. Grijsen, F. C. Hillen, E. L. Noach, and A. W. Sim (1971) 1-Hydroxy-3-amino-pyrrolidone-2(HA-966): A new GABA-like compound, with potential use in extrapyramidal diseases. Br. J. Pharmacol. 43: 514-535.

Bristow, D. R., N. G. Bowery, and G. N. Woodruff (1986) Light microscopic autoradiographic localisation of $\left[{ }^{3} \mathrm{H}\right]$ glycine and $\left[{ }^{3} \mathrm{H}\right]$ strychnine binding sites in rat brain. Eur. J. Pharmacol. 126: 303308.

Clarke, G., and D. W. Straughan (1977) Evaluation of the selectivity of antagonists of glutamate and acetylcholine applied microiontophoretically onto cortical neurones. Neuropharmacology 16: 391398.

Curtis, D. R., G. A. R. Johnston, C. J. A. Game, and R. M. McCulloch (1973) Antagonism of neuronal excitation by 1-hydroxy-3-aminopyrrolidone-2. Brain Res. 49: 467-470.

Davies, J., and J. C. Watkins (1972) Is 1-hydroxy-3-amino- pyrrolidone-2 (HA-966) a selective excitatory amino acid antagonist? Nature New Biol. 328: 61-63.

Davies, J., and J. C. Watkins (1973a) Microelectrophoretic studies on the depressant action of HA-966 on chemically and synaptically excited neurones in the cat cerebral cortex and cuneate nucleus. Brain Res. 59: 311-322.

Davies, J., and J. C. Watkins (1973b) Antagonism of synaptic and amino acid induced excitation in the cuneate nucleus of the cat by HA-966. Neuropharmacology 12: 637-640.

Dingledine, R. (1986) NMDA receptors: What do they do? Trends. Neurosci. 9: 47-49.

Evans, R. H., A. A. Francis, and J. C. Watkins (1978) $\mathrm{Mg}^{2+}$-like selective antagonism of excitatory amino acid-induced responses by $\alpha, \xi$-diaminopimelic acid, D- $\alpha$-aminoadipate and HA-966 in isolated spinal cord of frog and immature rat. Brain Res. 148: 536-542.

Evans, R. H., A. A. Francis, A. W. Jones, D. A. S. Smith, and J. C. Watkins (1982) The effects of a series of $\omega$-phosphonic $\alpha$-carboxylic amino acids on electrically evoked and amino acid induced responses in isolated spinal cord preparations. Br. J. Pharmacol. 75: 65-75.

Fletcher, E. J., and D. Lodge (1988) Glycine reverses antagonism of $\mathrm{N}$-methyl-D-aspartate (NMDA) by 1-hydroxy-3-aminopyrrolidone2 (HA-966) but not by D-2-amino-5-phosphonovalerate (D-AP5) on rat cortical slices. Eur. J. Pharmacol. 151: 161-162.

Foster, A. C, and G. E. Fagg (1987a) Taking apart NMDA receptors. Nature 329: 395-396.

Foster, A. C., and G. E. Fagg (1987b) Comparison of L- $\left[{ }^{3} \mathrm{H}\right]$ glutamate, D- $\left[{ }^{3} \mathrm{H}\right]$ aspartate, DL- $\left[{ }^{3} \mathrm{H}\right] \mathrm{AP} 5$ and $\left[{ }^{3} \mathrm{H}\right] \mathrm{NMDA}$ as ligands for NMDA receptors in crude postsynaptic densities from rat brain. Eur. J. Pharmacol. 133: 291-300.

Hamill, O. P., A. Marty, E. Neher, B. Sakmann, and F. J. Sigworth (1981) Improved patch-clamp techniques for high-resolution current recording from cells and cell-free patches. Pfluegers Arch. 391: 85100.

Harrison, N. L., and M. A. Simmonds (1985) Quantitative studies on 
some antagonists of $\mathrm{N}$-methyl-D-aspartate in slices of rat cerebral cortex. Br. J. Pharmacol. 84: 381-391.

Honore, T., and M. Nielson (1985) Complex structure of quisqualatesensitive glutamate receptors in rat cortex. Neurosci. Lett. 54:27-32.

Johnson, J. W., and P. Ascher (1987) Glycine potentiates the NMDA response in cultured mouse brain neurones. Nature 325: 529-531.

Kaplan, F. S., C. T. Brighton, M. J. Boytim, M. E. Selzer, V. Lee, K. Spindler, D. Silberberg, and J. Black (1986) Enhanced survival of rat neonatal cerebral cortical neurons at subalmospheric oxygen tensions in vitro. Brain Res. 384: 199-203.

Kemp, J. A., and A. M. Sillito (1982) The nature of the excitatory transmitter mediating $X$ and $Y$ cell inputs to the cat dorsal lateral geniculate nucleus. J. Physiol. 323: 377-391.

Kemp, J. A., A. C. Foster, and E. H. F. Wong (1987) Non-competitive antagonists of excitatory amino acid receptors. Trends Neurosci. 10: 294-298.

Kemp, J. A., A. C. Foster, P. D. Leeson, T. Priestley, R. Tridgett, I.. L. Iversen, and G. N. Woodruff (1988) 7-Chlorokynurenic acid is a selective antagonist at the glycine modulatory site of the N-methylD-aspartate receptor complex. Proc. Natl. Acad. Sci. (US 1 ) 85: 65476550 .

Kleckner, N. W., and R. Dingledine (1988) Requirement for glycine in activation of NMDA receptors expressed in Xenopus oocyles. Science 241: 835-837.

Kloog, Y., R. Haring, and M. Sokolovsky (1988) Kinetic characterisation of the phencyclidine- $\mathrm{N}$-methyl-D-aspartate receptor interaction: Evidence for a steric blockade of the channel. Biochemistry 27: 843-848.

Menon, M. K. (1981) Demonstration of the antimyoclonic effect of 1-hydroxy-3-amino-pyrrolidone-2 (HA-966) using a new animal model. Life Sci. 28: 2865-2868.
Monaghan, D. T., and C. W. Cotman (1985) Distribution of NMDAsensitive $\mathrm{L}-\left[{ }^{3} \mathrm{H}\right]$ glutamate binding sites in rat brain as determined by quantitative autoradiography. J. Neurosci. 5: 2909-2919.

Nowak, L., P. Bregestovski, P. Ascher, A. Herbert, and A. Prochiantz (1984) Magnesium gates glutamate-activated channels in mouse central neurones. Nature 307: 462-465.

Reynolds, I. J., S. N. Murphy, and R. J. Miller (1987) ${ }^{3} \mathrm{H}$-labelled MK-801 binding to the excitatory amino acid receptor complex from rat brain is enhanced by glycine. Proc. Natl. Acad. Sci. USA 84:77447748 .

Simon, J. R., J. F. Contrera, and M. J. Kuhar (1976) Binding of $\left.{ }^{3} \mathrm{H}\right]$ kainic acid, an analogue of $\mathrm{L}$-glutamate, to brain membranes. $\mathrm{J}$. Neurochem. 26: 141-147.

Snell, L. D., R. S. Morter, and K. M. Johnston (1987) Glycine potentiates $\mathrm{N}$-methyl-D-aspartate-induced $\left[{ }^{3} \mathrm{H}\right] \mathrm{TCP}$ binding to rat cortical membranes. Neurosci. Lett. 83: 313-317.

Thomas, J. W., W. F. Hood, J. B. Monahan, P. C. Contreras, and T L. O'Donohue (1988) Glycine modulation of the phencyclidine binding site in mammalian brain. Brain Res. 442: 396-398.

Watkins, J. C., and R. H. Evans (1981) Excitatory amino acid transmitters. Annu. Rev. Pharmacol. Toxicol. 21: 165-204.

Wong, E. H. F., J. A. Kemp, T. Priestley, A. R. Knight, G. N. Woodruff, and L. L. Iversen (1986) The anticonvulsant MK-801 is a potent N-methyl-D-aspartate antagonist. Proc. Natl. Acad. Sci. USA 83: 7104-7108.

Wong, E. H. F., A. R. Knight, and R. Ransom (1987) Glycine modulates $\left[{ }^{3} \mathrm{H}\right] \mathrm{MK}-801$ binding to the NMDA receptor in rat brain. Eur. J. Pharmacol. 142: 487-488.

Young, A. B., and S. H. Snyder (1974) Strychnine binding in rat spinal cord membranes associated with the synaptic glycine receptor: Cooperativity of glycine interactions. Mol. Pharmacol. 10:790-809. 